\title{
Digitising Patterns of Power (DPP): Applying Digital Tools in the Analysis of Political and Social Transformations in the Historical Region of Macedonia, 12th-14th Centuries
}

\author{
Mihailo St. Popović* and Veronika Polloczek
}

The project "Digitising Patterns of Power (hereafter DPP) is funded within the programme "Digital Humanities: Langzeitprojekte zum kulturellen Erbe«of the Austrian Academy of Sciences for a period of four years (2015-2018). It is hosted at the Institute for Medieval Research (IMAFO) of the same Academy and unites as a cluster project various experts from the fields of medieval history, Byzantine studies, historical geography, archaeology, geography, cartography, geographical information science (GISc) and software engineering. The present article elaborates on the authors' case study, "The Historical Region of Macedonia (12th-14th centuries): The Transformation of a Medieval Landscape«within DPP. It focuses, on the one hand, on the macro-level of political concepts in the Southern Balkan Peninsula from the 12th to the 14th centuries (especially from the expansion of the Serbian medieval kingdom to the South under King Stefan Uroš II Milutin until the death of Tsar Stefan Uroš IV Dušan, i.e. from 1282 until 1355), and, on the other hand, on the micro-level on the border zones and cross-border societies between the medieval Serbian kingdom and the Byzantine Empire in Byzantine Macedonia in the same period. The initial point of research is formed by the medieval written sources, i.e. Serbian and Byzantine charters as the main corpus, as well as other selected written sources from the medieval Serbian kingdom. The sources are analysed from the viewpoint of the aforesaid research questions and strongly based on methods derived from Historical Geography (especially on those of the long-term project Tabula Imperii Byzantini (TIB) of the Austrian Academy of Sciences). Special attention is given to the analysis of formulations with regard to the Serbian expansion within the area of research; the acquisition of new territories and their administrative incorporation on the macro-level; and to the localisation of conquered settlements with related settlement typologies, as well as to the change of local elites (prosopography) and their interaction with local nomads (i.e. Vlachs) on a micro-level. Finally, digital tools for storing data, mapping and visualisation, which have been developed by DPP, are presented.

* Correspondence details: Doz. Mag. Dr. Mihailo Popović (Principal Investigator of DPP), Institute for Medieval Research, Department of Byzantine Studies, Austrian Academy of Sciences, Hollandstraße 11-13, 1020 Vienna, Austria. Email: Mihailo.Popovic@oeaw.ac.at. 
Keywords: digital humanities; history; medieval history; Byzantine studies; historical geography; archaeology; spatial analysis; cartography; GIS; GIScience; WebGIS; software engineering

\section{Introduction}

The project "Digitising Patterns of Power (DPP): Peripherical Mountains in the Medieval World«(hereafter, DPP) is a digital cluster project of the Institute for Medieval Research (IMAFO; director: Univ.-Prof. Dr. Walter Pohl) of the Austrian Academy of Sciences and is funded within the programme "Digital Humanities: Langzeitprojekte zum kulturellen Erbe «of the same Academy for the duration of four years (January 1, 2015 to December 31, 2018). ${ }^{1}$ DPP unites various experts from the fields of Medieval History, Byzantine Studies, Historical Geography, Archaeology, Geography, Cartography, Geographical Information Science (GISc) and Software Engineering. In order to achieve the aims of the project the "Team Institute for Medieval Research «(Austrian Academy of Sciences) is cooperating with an external project partner, namely the »Team Department of Geography and Regional Research «(University of Vienna). ${ }^{2}$

DPP focuses on the depiction and analysis of space and place in medieval written sources, the interaction between built and natural environments, the appropriation of space and the emergence of new political, religious and economic structures of power. Moreover, DPP is a cutting-edge project within Digital Humanities and uses as well as develops digital tools for data-acquisition, data-management, processing and analysis, visualisation, communication and publication. By following such an approach, it envisages gaining new insights and innovative research results which could not otherwise be achieved solely by traditional methods. DPP compares five regions of the medieval world (cf. Fig. 1): the Carolingian Eastern Alps (8th-9th centuries), the March/Morava-Thaya/Dyje border region (7th-11th centuries), the Herzheimer Family Chronicle (613-1506), the historical region of Macedonia (12th-14th centuries), and historical Southern Armenia (5th-11th centuries).

\section{The case studies}

Five case studies of the European as well as Asian Middle Ages furnish insights into the development and sustainment of power in a spatial context. A focus is put on mountainous areas and the interaction between the development of power and the natural environment. These case studies share a common basis in mountainous ecologies, in their position on the peripheries of imperial spheres (Frankish Realm, Byzantine Empire, Arab Caliphate), and the specific framework provided by these conditions for the emergence and dynamics of political and socio-economic structures.

1 This article derives from scholarly results achieved in the project "Digitising Patterns of Power (DPP): Peripherical Mountains in the Medieval World«within the programme "Digital Humanities: Langzeitprojekte zum kulturellen Erbe«(DH 2014/10) at the Institute for Medieval Research (IMAFO) of the Austrian Academy of Sciences. Cf. on both teams of the project: dpp.oeaw.ac.at/index.php?seite=Team (retrieved 25 January 2017). 


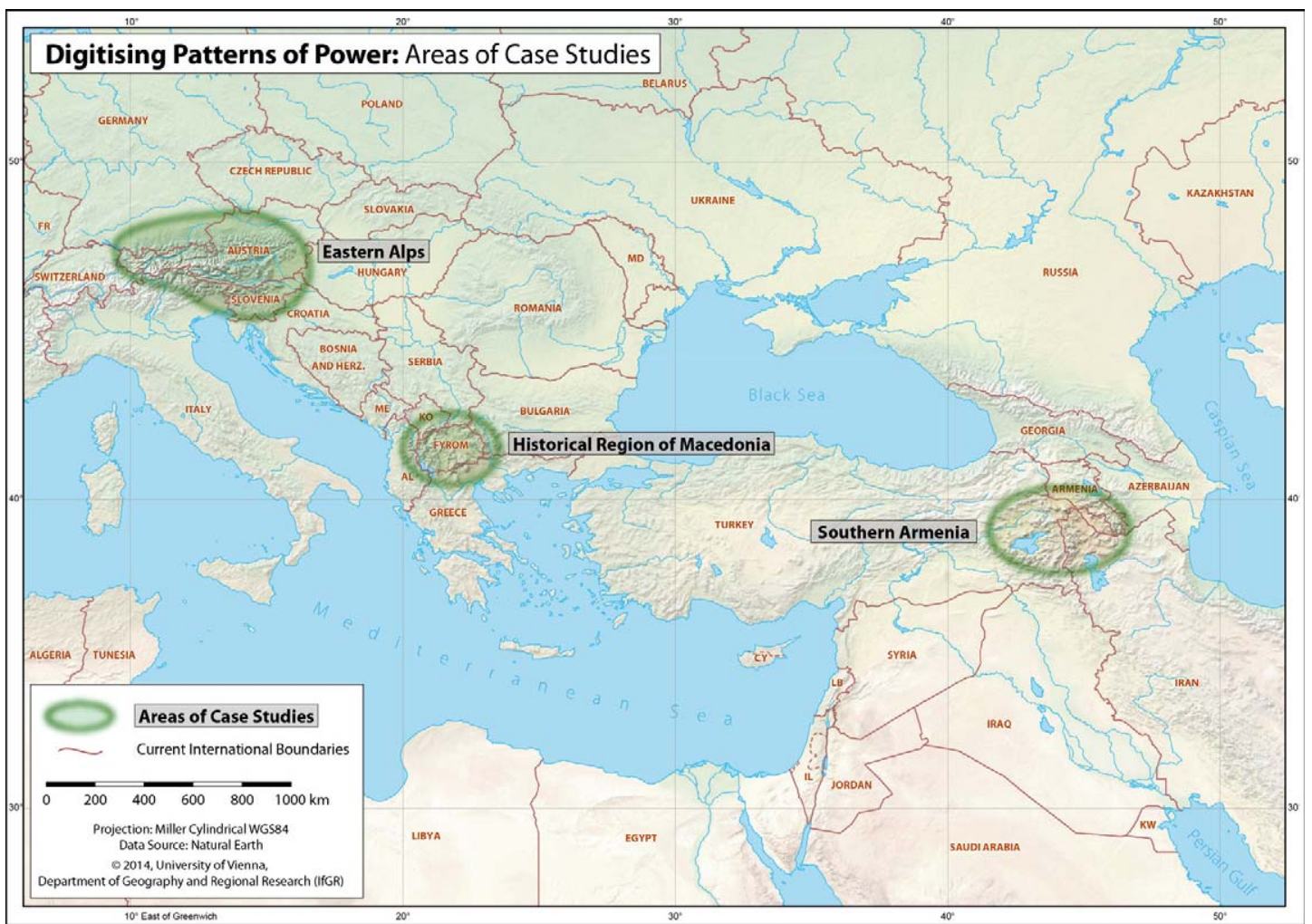

Fig. 1: The Five Case Studies within DPP

Case study: "The Historical Region of Macedonia (12th-14th centuries): The Transformation of a Medieval Landscape"

The present article focuses on the authors' case study within DPP, namely »The Historical Region of Macedonia (12th-14th Centuries): The Transformation of a Medieval Landscape«, and elaborates on several of the aforesaid aspects. This case study builds upon the manifold data provided by the volume Tabula Imperii Byzantini (TIB) 16 entitled "Macedonia, Northern Part «by the same authors and focuses on the territory of present-day Macedonia (the former Yugoslav Republic of Macedonia). ${ }^{3}$

The historical region of Macedonia, being at the crossroads of Orthodoxy, Roman Catholicism and Islam in the heart of the Balkan peninsula, is described in a large variety of written sources of the past and is distinguished by a remarkable richness of monuments (cultural heritage), especially for the period from the 12th to the 14th centuries. This case study focuses on the transformation of the historical region of Macedonia from a Byzantine province into an area of military expansion and political acquisition by the Serbian medieval kingdom/ empire. This process had a direct impact on settlement patterns in the region, the redistribution of landed property, the monastic communities, the interplay between the resident population and nomads (especially the Vlachs) and the building of new infrastructure (monuments). 
Of special interest are the administrative centres and the venues of medieval state councils (as in-between category of temporary and durable places of settlement) of the Serbian rulers from the 12th to the 14th centuries. Research is conducted on four target areas, namely: the city of Skopje and its environs, the monastery of Lesnovo and its landed property, the city of Prilep and its surroundings, and on the valley of the river Strumica (cf. Fig. 2).

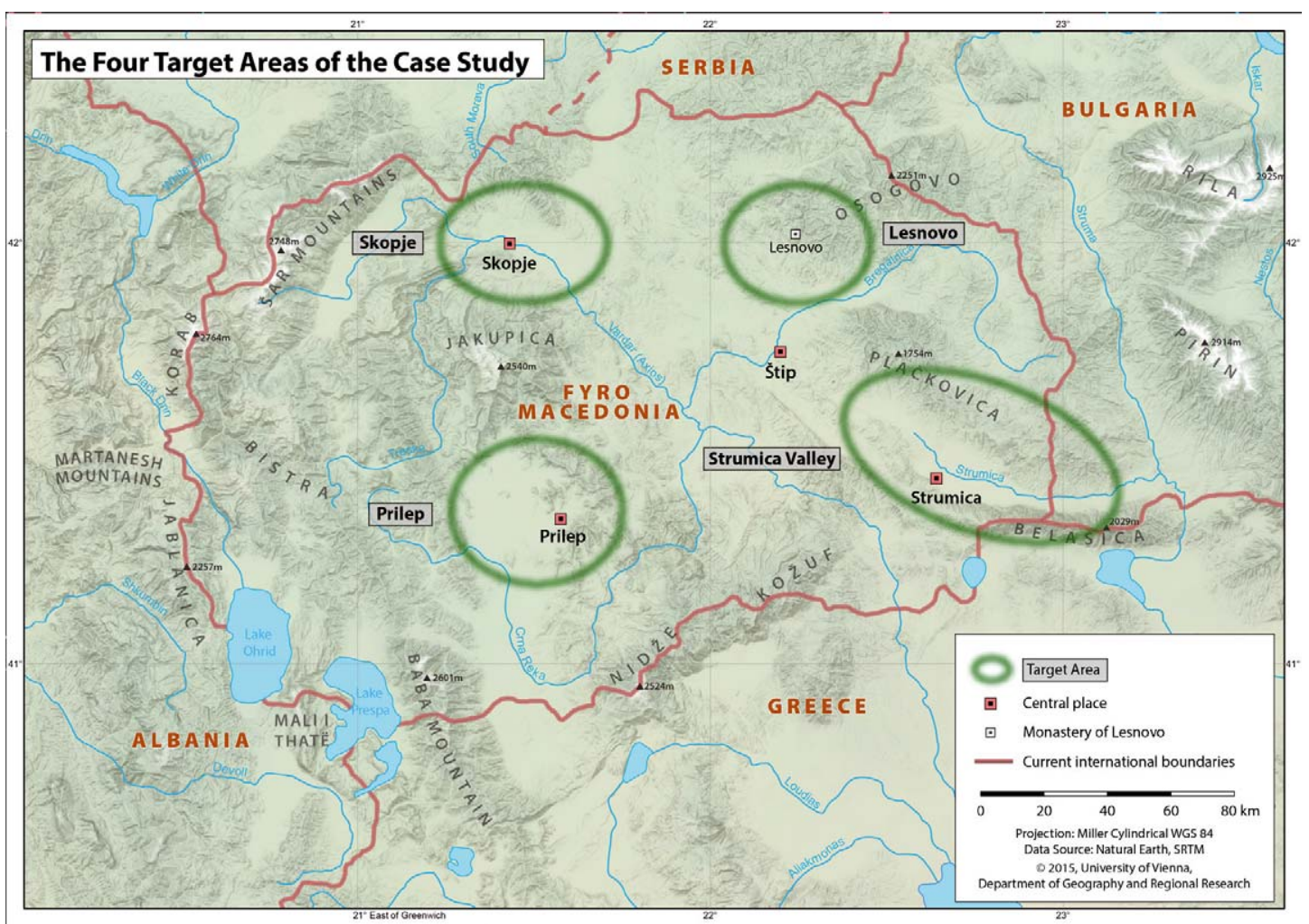

Fig. 2: The Four Target Areas in the Historical Region of Macedonia

\section{The sources}

As the main textual corpus for the analysis of this process, the case study draws primarily upon published Serbian and Byzantine charters, which have the capacity to shed new light on several aspects of settlement patterns, borders and migration in Byzantine Macedonia. Byzantine charters are taken into account selectively (i.e. from case to case): if they prove to be relevant for the same border zones as the Serbian ones, this enables a direct comparison of specific terms for the designation of settlements from a linguistic point of view, and us to illustrate a cultural transfer in the border zones between the two rival domains. Although these sources have been published with remarkable endeavour in the past 150 years, they have only been evaluated to a certain extent so far as regards the research topic being elaborated here. Since the case study is focusing on pre-Ottoman Macedonia, Ottoman charters and tax registers (defter) will not be taken into account in the envisaged research.

\section{Research questions}

The European continent as a whole and the European Union in particular are facing an increasingly dynamic period of internal as well as external immigration. News agencies frequently report on the latter by monitoring the current two main routes of immigration to the European Union, namely, via Southern Italy by sea and via the border between Greece and Turkey by land and by sea. 
In medieval societies the question of migration is closely connected with the definition as well as the representation of borders. Maps in historical atlases are designed to provide clear-cut lines of political formations and empires ${ }^{4}$; but these do not reflect the reality of civilizations neither in Antiquity, nor in the Middle Ages and in Early Modern Times. ${ }^{5}$ Of course, these atlases have the explicit aim of giving an overview to the general reader. Still, their representations are not helpful with respect to the question of interactions between different societies on a macro-level as well as on a micro-level. The dynamics of borders simultaneously shapes the dynamics of settlement patterns as well as of migration and of transportation networks. These factors in turn, lead directly to the notion of transterritorial history.

If we go into detail and focus on the borders of the Byzantine Empire, we immediately realize that relevant research is mostly focused on the macro-level be it in Byzantine Asia Minor $^{6}$ or in Byzantine Macedonia ${ }^{7}$. That is why the focus of this case study within DPP is put, on the one hand, on the macro-level of political concepts in the Southern Balkan Peninsula from the end of the 13th until the middle of the 14th century, and, on the other hand, on the micro-level, on the border zones and cross-border societies between the medieval Serbian kingdom and the Byzantine Empire in Byzantine Macedonia ${ }^{8}$ in the same period. Although substantial publications exist on the population of as well as on migration in Byzantine Macedonia ${ }^{9}$, there is still an urgent need for thorough research on the dynamics of cross-border societies based on written sources and toponyms.

The case study aims at explaining in a holistic approach (1) the confrontation of political concepts and actors in Byzantine Macedonia, and (2) the change of power starting from the expansion of the Serbian medieval kingdom to the South under King Stefan Uroš II Milutin until the death of Tsar Stefan Uroš IV Dušan (i.e. from 1282 until 1355), by addressing two interrelated research questions.

By combining the dynamics of borders and cross-border societies, we possess the means to reconstruct the medieval landscape of Byzantine Macedonia from the 12th to the 14th centuries. ${ }^{10}$ Thus, it will be necessary and fruitful to expand the samples presented here (see below) with the aim of obtaining an overall picture of the entire area. Of vital importance is the analysis of additional border zones between the Serbian medieval kingdom and the Byzantine Empire - the target areas of the Strumica Valley, Lesnovo, Skopje and Prilep and their respective surroundings (cf. Fig. 2) - on the basis of the aforesaid written sources,

5 See on this issue for example: Abulafia and Berend, Medieval Frontiers; Baramova et al., Bordering Early Modern Europe; Jaspert, Grenzen und Grenzräume im Mittelalter; Schwara, Rediscovering the Levant; Smith, Networks; Smith, Territories, Corridors, and Networks.

6 Cf. for example: Haldon and Kennedy, Arab-Byzantine Frontier; Eger, Islamic-Byzantine Frontier; Kaegi, Frontier.

7 Bakalopulos, Limites de l'empire byzantin; Naumov, Istorii serbo-vizantijskoj granicy; Petrovski, Prilog; Popović, Forteresses; Škrivanić, Južnim i jugoistočnim granicama; Stephenson, Byzantine Frontier in Macedonia; Stephenson, Byzantium's Balkan Frontier; Stephenson, Byzantium's Balkan Frontier; Tomoski, Ispravki i dopolnenija; Živojinović, Frontière serbobyzantine.

8 Cf. on the definition of Byzantine Macedonia: Koder, Macedonians and Macedonia.

9 For example: Djoković, Stanovništvo istočne Makedonije; Kalić, Les migrations serbes dans les Balkans; Lefort, Population et peuplement; Moustakas, Demographic Crisis.

10 Cf. in detail: Popović, Siedlungsstrukturen im Wandel; Popović, Networks of Border Zones; Popović, Espace impérial. 
a reconstruction of their settlement patterns and the visualisation of the development as well as of the degradation of the settlements themselves. A further field of research, which is closely connected to the shifting borders and is also addressed in the case study, is the change of ruling elites in these border zones. We will witness a flight of Byzantine noblemen and landowners from their landed properties in the wake of the expansion of the Serbian medieval kingdom and a redistribution of abandoned land and of privileges to Serbian noblemen by the Serbian rulers.

Moreover, the acquired data of the case study is embedded into the already existing DPP OpenAtlas Database (see below), which will enable a synoptic analysis and visualisation of the data with the means of modern GIS-based cartography for the interested public via a web-portal.

The two main research questions are outlined as follows:

\section{Rivalling political concepts: Byzantium and the "Medieval Serbian Oecumene"}

In the year 1969 the geographer Francis W. Carter published a scholarly article based on graph theoretical methods entitled "An Analysis of the Medieval Serbian Oecumene: A Theoretical Approach. $«^{11}$ The first research question of the case study does not envisage a discourse on the potential usefulness of graph theoretical methods in the historical geography of Byzantium, but will focus on the very terminology of the title of Carter's article. An investigation of the usage of the expression "Medieval Serbian Oecumene «based on internet search engines reveals that Carter's application of this term in his article occurred then for the first and the last time. Thus, it has never since been taken into account by any other scholar for any further interpretation within the field of Byzantine and Serbian Studies.

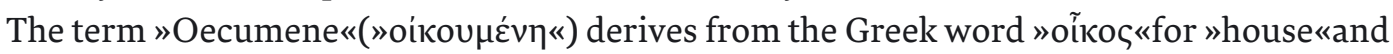
has a fundamental meaning for the study of settlements, of settlement patterns and finally

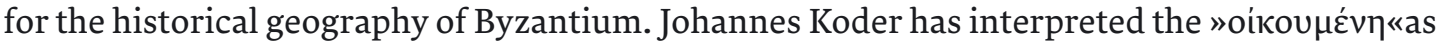
"den von Menschen besiedelten Raum«and »die von Menschen bewohnte Landschaft«in his many publications on this topic. ${ }^{12}$ At this point it should be stressed that the term "Byzantine Oecumene«has not been universally accepted within the field of Byzantine Studies, but that it has been, for example, reshaped by Dimitri Obolensky into "Byzantine Commonwealth «. ${ }^{13}$ Obolensky extracted several elements, which according to him were adopted by the ruling and educated classes of the East European peoples and which led to a common cultural tradition. ${ }^{14}$ In his most recent monograph entitled »The Byzantine Republic. People and Power in New Rome ${ }^{15}$, Anthony Kaldellis criticizes the term »Byzantine Commonwealth«and argues that Byzantium must be understood as a republic in the Roman tradition and that the Byzantine politeia was the continuation of the ancient res publica. ${ }^{16}$ 
So, while the discourse on the political, diplomatic, economic, ecclesiastical, religious and cultural sphere of Byzantium is evolving anew, we would like to leave aside the terms "Byzantine Commonwealth «and politeia and focus on the "Byzantine Oecumene«. The crucial question from the viewpoint of the aforesaid case study within DPP, and, specifically, on the macro-level of historical geography is, whether the existence of the "Byzantine Oecumene «would exclude the existence of any other »Oecumene«in Byzantium's (former) sphere of influence? Would Byzantium's universality render a »Medieval Serbian Oecumene«impossible from the start?

Firstly, this question shall be approached from a geographical point of view. Carter states on this issue: "In terms of the medieval period, with which we are primarily concerned in this article, this [scilicet »oecumene"] means a fertile soil, well cultivated within the limits of contemporary technology, a population dense enough to derive maximum advantage from local resources and generally a long distance commerce to enable it to obtain materials not locally available. [...] such an area must have considerable advantages in order to permit it to perform within itself against encroachment and conquest from neighbouring areas and it must have been capable at an early date of generating a surplus income above the subsistence level, necessary to equip armies and to play the role in contemporary power politics that territorial expansion necessarily predicates. $\ll^{17}$

In accordance with this definition of an "oecumene"we shall question whether the medieval Serbian kingdom fulfilled the criteria elaborated by Carter. An assessment of this question is envisaged on the basis of, for the time being, selected medieval written sources and the related historic framework. A useful starting point for this line of thought is the Serbian conquest of Byzantine Macedonia, which according to Ljubomir Maksimović, was accomplished in four systematic phases in the period lasting from the early 13 th century until the middle of the 14th century (i.e., $a$. the beginning of the 13th century; $b$. the middle of the 13th century; $c$. during the reign of king Stefan Uroš II Milutin 1282-1321; $d$. after the year 1332 under king Stefan Uroš IV Dušan). ${ }^{18}$

In one of our recent articles ${ }^{19}$ we have argued that the third and fourth phases of the Serbian conquest of Byzantine Macedonia were of integral importance for the shaping of the "Medieval Serbian Oecumene«. We approached the research question from the textual evidence and from expressions as well as concepts in selected Serbian medieval sources, and not from the viewpoint of political and military history nor from the exact dating of events within the framework of Byzantino-Serbian relations. If we turn, for the time being, to the Serbian medieval source of »The Lives of the Serbian Kings and Archbishops «written by archbishop Danilo II (ca. 1270-1337) and his disciples, we are able to trace the theoretical outline provided by Carter.

17 Carter, Analysis of the Medieval Serbian Oecumene, 40.

18 Maksimović, Makedonija; the same article was published in Modern Greek: Maksimović, BYZANTINH MAKE $O N I A$. Also cf. Dinić, Hronologiju Dušanovih.

19 Popović, "The Medieval Serbian Oecumene«; the same article in Serbian: Popović, »Srednjovekovna srpska ekumena«. 
In the vita of the Serbian king Stefan Uroš II Milutin Danilo II describes, how the Byzantine Empire posed a political and military threat to the Serbian kingdom and how king Milutin succeeded in spreading his sphere of control:

"So, fürwahr, wollte der gütige Gott die Herrschaft über sein Vaterland ausbreiten, (wie es bis heute allen sichtbar ist). Es begab sich, daß sich in jenen Tagen das serbische Land in arger Bedrängnis (und Erniedrigung) befand. Denn der Machtbereich des griechischen Kaisertums reichte bis zum Ort Lipljan, und die Gewalttätigkeiten dieses Reiches mehrten sich, als wollte es die Herrschaft über das ganze Land dieses Christusliebenden ausdehnen und sogar ihn selbst [scilicet Stefan Uroš II Milutin] in die Rolle eines gehorsamen Knechtes zwingen. $\ll^{20}$

What we find in this quotation is an obvious hint at a clear delimitation between the Byzantine Empire and the Serbian kingdom, between the "sphere of rule of the Greek Empire«(drižava bo carǐstva grǐč̌skaago) stretching to the place of Lipljan (do města glagoljemaago Lipljana) and the "fatherland «(otǐčstvija jego) of the Serbian king. This "fatherland «has to be understood as the "core area «defined by Carter and which is an area in which a state originates (see above). This notion becomes evident by the introductory remark of Danilo II that »God wanted to spread the rule of his [scilicet Milutin's] fatherland «to new territories. ${ }^{21}$ The "core area «of the Serbian king, which is at the same time the "fatherland", constitutes the nucleus for the expansion of the Serbian kingdom at the expense of the "Byzantine Oecumene«in Byzantine Macedonia.

Is the "Byzantine Oecumene«perceived as "Oecumene«at all by Danilo II? The answer to this question lies - in our opinion - in the title of the Byzantine emperor as reflected in the "The Lives of the Serbian Kings and Archbishops". Danilo II uses several times the expression »Weltenkaiser «(svetomu $i$ viseljeniskomu caru kirı Anĭdroniku) $)^{22}$ for the Byzantine emperor Andronikos II Palaiologos (1282-1328), whose title bears witness to the fact that the Serbian side was well aware of the position of the emperor in Constantinople within the original "Byzantine Oecumene«. Furthermore, he is addressed as "Weltenkaiser des Neuen Rom, Konstantinopels, Kir Andronikos«(vǐseljenı̌skyimı̌ caremı̌ novago Rima Konǐstanĭtino-

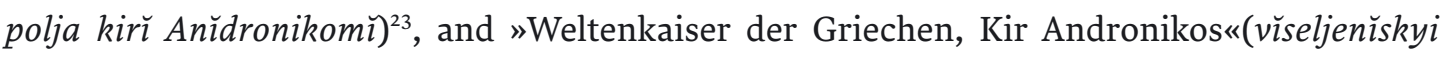
carĭ grǐkomǐ kirĭ Anĭdronikì) $)^{24}$.

As stated above, the term »fatherland«designates the "core area«of the Serbian kingdom, which can regularly be found in the work of Danilo II and his disciples starting with the vita of the Serbian king Stefan Uroš I and leading up to that of Stefan Uroš IV Dušan. ${ }^{25}$ Crucial for our research question is the moment when the "fatherland «of the Serbian kings in the sense of a "core area"was visibly transformed through territorial acquisition into the "Medieval Serbian Oecumene«according to the term as defined by Carter. From our point of

20 German translation from: Hafner, Serbisches Mittelalter, 150.

21 Cf. on the original quotations from the source: Danilo II, Životi kraljeva i arhiepiskopa srpskih, ed. Daničić, 107.

22 Danilo II, Životi kraljeva i arhiepiskopa srpskih, ed. Daničić, 126, also cf. 146, 164, 168; Hafner, Serbisches Mittelalter, 169, also cf. 184, 189, 207, 211.

23 Danilo II, Životi kraljeva i arhiepiskopa srpskih, ed. Daničić, 141; Hafner, Serbisches Mittelalter, 184.

24 Danilo II, Životi kraljeva i arhiepiskopa srpskih, ed. Daničić, 148; Hafner, Serbisches Mittelalter, 191.

25 Hafner, Serbisches Mittelalter, 54, 56-58, 62, 64, 71, 74, 84, 87, 94-96, 147f., 150f., 153, 155f., 160, 163-166, 171, 173f., 183, 187, 191f., 195f., 213, 215, 221-227, 229-235, 240-244, 251, 256f., 259-267, 269, 271, $273 f$. 
view Danilo II describes this very process in the vita of King Milutin, when the Serbian ruler conquered the regions of Polog, Ovče Polje, Zletovo, Pijanec and the town of Skopje. ${ }^{26}$ It is in the expressions "he added them [scilicet the newly conquered territories] to the domain of his fatherland «( $i$ priloži ih ǐ kì drižavě otǐčstvija svojego) and »after having pacified all places

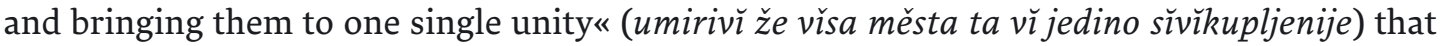
the »Medieval Serbian Oecumene«becomes manifest. ${ }^{27}$ Indeed, king Milutin had started to expand into new territories that had the considerable advantages of being - in accord with Carter's definition - capable of performing against encroachment and conquest from neighbouring areas, generated a surplus income above the subsistence level ${ }^{28}$ and had the potential to equip armies and to play a role in contemporary power politics that territorial expansion necessarily predicates - thus creating his very own »oecumene«.

After the conquest of this part of Byzantine Macedonia a significant change of local elites took place, which is attested by Danilo II in his work ${ }^{29}$ and which forms at the same time the incentive for the second research question within the DPP case study.

Based on the quoted sources we would argue strongly, for the time being, that the "Medieval Serbian Oecumene«had started to take shape during the rule of king Milutin; this will be further elaborated within the case study based on additional written sources. Milutin's policy was continued by his son and successor Stefan Uroš III Dečanski (1321-1331), who expanded his father's »oecumene «by winning over the Byzantine elite in Byzantine Macedonia or by empowering his noblemen, which is reported by »The Lives of the Serbian Kings and Archbishops «. ${ }^{30}$

Having in mind the reign of Stefan Uroš IV Dušan, both of his predecessors, Stefan Uroš II Milutin and Stefan Uroš III Dečanski, established their own "small Serbian Oecumene«besides the »huge Byzantine Oecumene«, in which we discern a parallel local concept and not an attempt to substitute the universal Byzantine concept. A new aspect of the Serbian approach was added by King Dušan; he used the then recently formed "Medieval Serbian Oecumene«in the power politics of his time with the clear aim of taking over the "Byzantine Oecumene «and replacing the emperor in Constantinople as the emperor of the Serbs and Greeks. ${ }^{31}$ King Dušan reached out to the »Byzantine Oecumene«, but his attempt failed due to his unexpected death in 1355 . What followed was not only a weakening of the dynamic of the Serbian expansion against the Byzantine Empire and a fragmentation of the Serbian Empire, but also a disintegration of the "Medieval Serbian Oecumene«into confined local dominions. Neither were the local Serbian rulers and noblemen able to sustain the borders of Dušan's Empire, nor did they succeed in preserving the core of the »Medieval Serbian Oecumene«.

Finally, we would like to shift our view from the macro-level of the definition of "oecumene «to the micro-level and the question of how we can determine the extent of the "Medieval Serbian Oecumene«on the ground in Byzantine Macedonia; this is another core research question of this DPP case study. As the first possible parameter on the micro-level

26 Hafner, Serbisches Mittelalter, 152.

27 Danilo II, Životi kraljeva i arhiepiskopa srpskih, ed. Daničić, 109.

28 Cf. on this issue: Koder, Macedonians and Macedonia, 23.

29 Hafner, Serbisches Mittelalter, 152.

30 Hafner, Serbisches Mittelalter, 243.

31 Hafner, Serbisches Mittelalter, 266. Cf. on this issue: Pirivatrić, Ulazak Stefana Dušana. 
we could resort to the venues of the Serbian state councils as markers of the extension of the "Medieval Serbian Oecumene«. A succinct overview of this topic was given by Miloš Blagojević and Dejan Medaković. ${ }^{32}$ They list the locations of state councils in the medieval Serbian kingdom/empire, which are shown on the map in Fig. 3 (see below). ${ }^{33}$

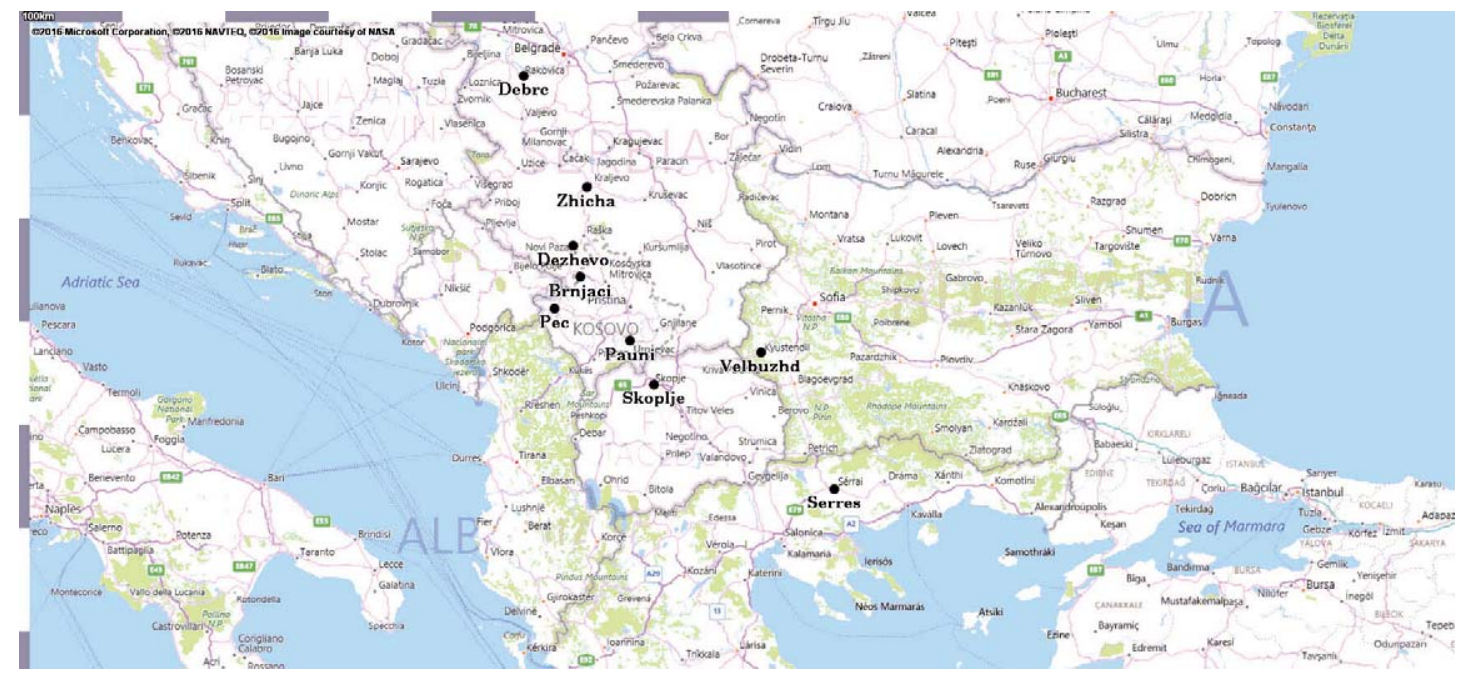

Fig. 3: Venues of the Serbian State Councils as Markers of the Extension of the "Medieval Serbian Oecumene"

As for the second parameter, we could consider those locations from where the Serbian rulers issued their charters. In this respect a very vivid example is the reign of Stefan Uroš IV Dušan, during which sixteen different places are mentioned in the sources (see below, Fig. 4). ${ }^{34}$ In both cases the data provided helps us to shape our picture of the extent of the "Medieval Serbian Oecumene«by introducing these places as "Signs of Power «to the DPP OpenAtlas Database, on which we will elaborate below.

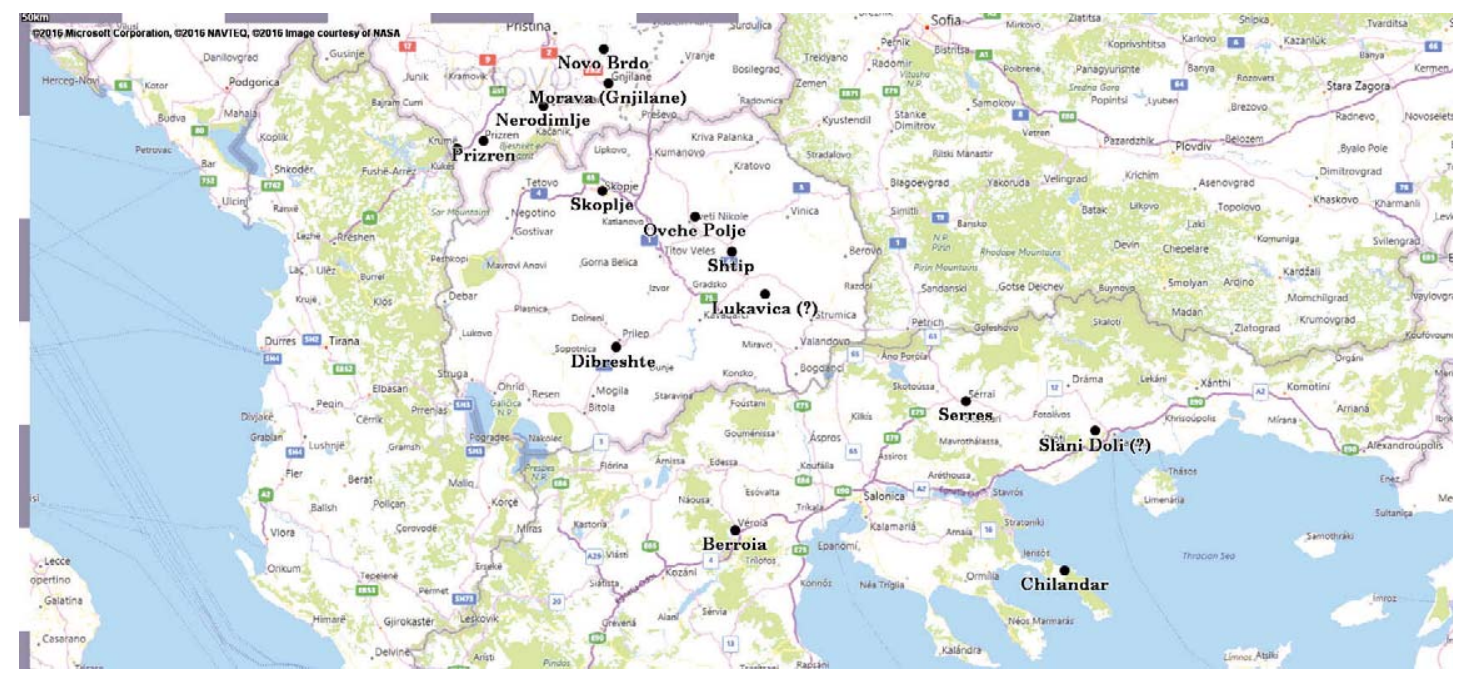

Fig. 4: Places, where Stefan Uroš IV Dušan issued his Charters

32 Blagojević and Medaković, Istorija srpske državnosti, 177-185.

33 Radojčić, Srpski državni sabori, 83-157; Ćirković and Blagojević, Zbor.

34 Based on: Slaveva and Mošin, Srpski gramoti. 


\section{Cross-border societies and elite change in Byzantine Macedonia}

The area of this research topic comprises in principle the whole territory of (the former Yugoslav Republic of) Macedonia as well as the south-western part of Bulgaria, and in detail those four target areas (see above, Fig. 2) mentioned above. The correlation of the dynamics of settlement patterns and of changing borders is evident. Several scholars have tried to reconstruct on a macro-level in Byzantine Macedonia ${ }^{35}$ the course of the border between the Serbian medieval kingdom and the Byzantine Empire. However, these approaches have so far neglected to use data on the development - that is, from hamlet to village - or on the degradation - from village to deserted village - of settlements deriving from medieval Serbian and Byzantine charters (see above) in order to comprehend the dynamics of the respective borders on a micro-level.

A vivid case study within this framework is, for example, the deployment of the border between Serbs and Byzantines in the upper valley of the river Strumica in the first half of the 14th century. Whereas the older bibliography focused exclusively on the dating of the Serbian conquest of the towns of Štip and of Strumica, we have looked for evidence to trace the border, that is the zones of influence and their contours, between both realms and the moment of its movement into one or the other direction according to alternating military successes and changing settlement patterns. ${ }^{36}$

The dynamics of borders simultaneously shapes the dynamics of settlement patterns as well as of migration and of transportation networks. The critique of the simplicity of the static image given by printed atlases (as above) requires the introduction of suitable alternatives from the field of Digital Humanities ${ }^{37}$, which are offered by the digital tools developed by DPP (see below).

Rade Mihaljčić has highlighted the most important reasons for migration in the Serbian medieval kingdom, which hold true too for the Byzantine Empire, at least to a certain extent..$^{38}$ In order to profit from tax advantages, inhabitants of villages often fled to other feudal lords, to the towns or to foreign territories. They were also captured by various feudal lords and resettled or displaced by wars. In particular, the border zones between medieval realms in South-East Europe - that is the Byzantine Empire, Serbia and Bulgaria - witnessed a fluctuation in their populations. Further factors of migration were the clearing as well as the colonisation of new territories.

Basing himself on a Slavonic charter of the Serbian king Stefan Uroš IV Dušan from 1336, the renowned Byzantinist George Ostrogorski had already noted in 1951 that Byzantine noblemen living in the surrounding area of Štip, were deprived of their landed property and replaced by Serbian noblemen, who had arrived in the area in the wake of the Serbian expansion into Byzantine Macedonia. Moreover, Ostrogorski came to the conclusion that this

Cf. for example: Bartusis, Settlement of Serbs; Bartusis, Land and Privilege in Byzantium, 205; Ostrogorskij, Étienne Dušan.

36 Popović, Siedlungsstrukturen im Wandel; Popović, Altstraßenforschung; Popović, Flußtal.

37 Cf. on this topic for example: Popović, Historische Geographie und Digital Humanities, 66 f., 72.

38 Mihaljčić, Selišta. 
was not an isolated case of redistribution of landed property, but part of a broader picture of rapid political and military change: "En d'autres termes, après l'occupation de la région de Štip, les biens des pronoïaires locaux furent retirés à leurs maitres grecs et donnés à l'un des participants à la victorieuse offensive serbe. Il n'y a pas de doute qu'il ne s'agit pas ici d'un phénomène isolé. Le processus d'expropriation des feudataires byzantins au profit de la noblesse serbe, processus sur lequel ce document [scilicet the Serbian charter of 1336] nous conserve une donnée isolée, ne s'est pas limité à la région de Štip, mais accompagnait partout, inévitablement, le processus de la conquête des terres byzantines et fut certainement le but principal de cette conquête. [...] « ${ }^{39}$ Still in 1998 Mark Bartusis underlined that: »As for the demographic changes brought about by Dušan's conquest of Byzantine Macedonia, the Byzantine sources say little, and the Serbian sources say even less. « ${ }^{40}$

For example, in 1300 the Serbian king Milutin issued a Slavonic charter for the Monastery of Saint George-Gorg in the vicinity of Skopje, which draws a vivid picture of a rapid change of elites as described by Ostrogorski, and of a redistribution of property in and around Skopje. A clear indicator in this context is the emergence of the specific term

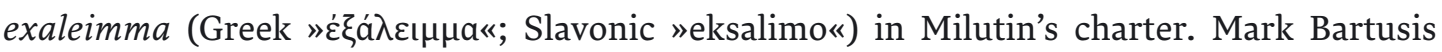
interprets exaleimma as "ruined properties «and states: "[...] an exaleimma was an escheated property, which reverted to the owner's lord (a private landlord or the state in its role as a landlord) as a result of the death or flight of its owner (usually a paroikos) without leaving a proper heir. ${ }^{41}$ Based on Milutin's charter we can localise exaleimmata in the village of Sulnje (today Gorno and Dolno Sonje). They are indicated as exaleimmata of Pasarel, Ilijas ('H $\lambda$ ías) and Ananze. In the vicinity of this village we find an exaleimma of the priest Kvočilo. Further exaleimmata are attested in the villages of (Markova) Sušica, Barovo, Gorno Sonje, Sopište, Krušopek and Preska. These passages from the respective medieval written source illustrate clearly that there was a process of devastation to the south and south-west of Skopje during the conflict between Byzantium and Serbia before the final Serbian conquest of the zone. Facing the Serbian expansion, the Byzantine proprietors fled the area, which is documented in the remarkable number of exaleimmata..$^{42}$

In the town of Skopje itself we are also able to trace the change of elites. After the conquest of the town by King Milutin, a large number of ruined houses is mentioned in the 1300 charter, which is without doubt a consequence of the Byzantino-Serbian conflict. In a recent article we have undertaken an analysis of Skopje's urban structure in medieval times based on Milutin's charter. ${ }^{43}$ In this context the Slavonic term "rĭpinije «requires our special

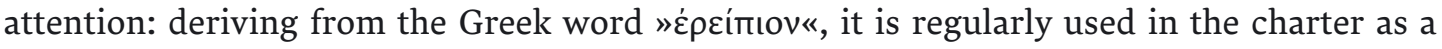
term for a ruin where the construction of a new building is possible. Basing ourselves again on Milutin's 1300 charter, we are able to discern that the Serbian king accomplished the change of elites in Skopje and its surroundings in three ways: firstly, by redistributing the exaleimmata of Byzantines, who had fled; secondly, by buying the property of Byzantines; and thirdly, there are hints in the charter that point to selected disappropriations. 


\section{Innovative aspects, methods and workflow}

By combining medieval political concepts with the dynamics of borders and cross-border societies, addressed in the two research questions, we now possess the means to reconstruct the evolution of the respective Serbian political concepts and the related military expansion in the Southern Balkan Peninsula (namely in Byzantine Macedonia) from the 12th to the 14th centuries on the macro-level, and the related border zones and cross-border societies between the medieval Serbian kingdom and the Byzantine Empire on the micro-level. A thorough analysis of published medieval Serbian (and selected Byzantine) charters sheds new light on aspects of borders, migration and language. Although these sources were published a long time ago, they have until now only been evaluated to a certain extent in regards to this project's research topic. Thus, it is necessary and fruitful to expand the examples presented here with the aim of obtaining an overall picture of the entire medieval space. Of vital importance is the analysis of the indicated border zones, namely the Four Target Areas (cf. Fig. 2) between the Serbian medieval kingdom and the Byzantine Empire. A further field of research, which is closely connected to the shifting borders and which is also addressed in this case study, is the change of ruling elites in the border zones and their relation to local nomads (especially the Vlachs).

We witness, for example, a flight of Byzantine noblemen and landowners from their landed properties in the wake of the expansion of the Serbian medieval kingdom, and a redistribution of abandoned land and of privileges to Serbian noblemen by the Serbian rulers. The analysis of the written sources leads to a substantial enrichment of the prosopographic data provided by the "Prosopographisches Lexikon der Palaiologenzeit (PLP) « ${ }^{44}$, especially with regard to the still missing Slavonic personalities and, thus, form the starting point for a corpus of these personalities. ${ }^{45}$

The initial point of the case study comes from the medieval written sources, namely Serbian and Byzantine charters as the main corpus, as well as other selected written sources from the medieval Serbian kingdom as outlined by Gerhard Podskalsky; ${ }^{46}$ sources from this group will be used selectively, i.e. if they prove to be useful and applicable for the aforesaid research questions. The sources are analysed from the viewpoint of the research questions and are strongly based on methods derived from historical geography (i.e. "Grundlagenforschung"), especially on the scholarly approach of the project "Tabula Imperii Byzantini (TIB) « ${ }^{47}$. Special attention is given to the analysis of formulations with regard to Serbian expansion in the area of research, the acquisition of new territories and their administrative incorporation on the macro-level, and to the localisation of conquered settlements with related settlement typologies as well as to the change of local elites (prosopography) on a micro-level..$^{48}$

The methodology and the current workflow in the case study evolved since the beginning of the project in January 2015 as follows:

44 Trapp, Prosopographisches Lexikon.

45 First steps in this direction were undertaken by: Šuica, Nemirno doba.

46 Podskalsky, Theologische Literatur des Mittelalters; Podskalsky, Briefe in der mittelalterlichen Literatur.

47 Cf. on the method of the TIB for example: Koder, Perspektiven der Tabula Imperii Byzantinii. 
a) Collection and reading of the respective Serbian and Byzantine charters in the area of research (namely on the Four Target Areas; cf. Fig. 2) by taking into consideration new editions and corrected dating.

b) Analysis of the respective charters regarding the research question as outlined in Rivalling Political Concepts: Byzantium and the "Medieval Serbian Oecumene". Here, the Serbian and Byzantine terminology of administrative terms and units as well as territories in the area of research is extracted, i.e. state council: sŭborŭ; administrative units: župa; oblast; hora, chōra; predeo; strana, perichōros, ta merē; thema; border zone: krajište. ${ }^{49}$

c) Analysis of the respective charters regarding the research question as outlined in Cross-Border Societies and Elite Change in Byzantine Macedonia, namely on the location of Byzantine/Serbian landed property, the related settlement, agricultural and economic terminology, to wit: village, selo, chorion; hamlet, zaselǐk, agridion; deserted village or place for a new settlement/settlement site, selište, agridion; ruined properties, eksalimo, exaleimma; clearing, trěbežb; (upper) town, gradŭ; lower town, marketplace, trŭgŭ; fair, panagjurŭ; monastery, manastyrü; church, crǔkva; ruined church, crŭkŭvište; a small monastic establishment, which is subordinate to a larger independent monastery, metohŭ; summer pasture, planina; winter pasture, zimovište; meadow, paša, pašište, zabělĭ; a temporary settlement of Vlachs, katunŭ; vineyard, vinogradŭ; water mill, voděnica; mill, mlinŭ; hunting ground, lovište; fishing ground, ribarije; mining, ruda; and the respective individuals involved (Byzantine/Serbian rulers, noblemen and feudal lords, vlastelĭ; Vlachŭ, Vlasi; katunař̆, čelǐnikĭ.)

d) Evaluation and inclusion of further sources if useful and applicable (for example chronicles and rulers' biographies, historiography, the Lives of Saints, travel literature, itineraries, inscriptions, seals and coins) in order to augment the acquired data.

e) Embedding of the respective data into the existing DPP OpenAtlas Database.

Data that is acquired in this workflow is on the one hand published in an analogue way through scholarly articles. ${ }^{50}$ On the other hand, the respective data is embedded into the existing DPP OpenAtlas Database, which is based on the open-source Database System OpenAtlas (www.openatlas.eu; retrieved 9 January 2017), and which stores its information based on the CIDOC-CRM (www.cidoc-crm.org; retrieved 9 January 2017), and is therefore, from a conceptual point of view, highly compatible and sustainable on an international level. Thus, we are able to store data on settlements and changing settlement typologies, agricultural and economic sites, the respective Byzantine and Serbian noblemen, their landed property, its localisation as well as the evaluated written sources in general (cf. Fig. 5, Fig. 6 and Fig. 7).

48 Cf. for example: Levi, On Microhistory; Szijártó, Arguments for Microhistory; Magnússon and Szijártó, Four Arguments for Microhistory.

49 Cf. on this issue: Božanić, Čuvanje prostora.

50 Popović, Herrschaftsgebiet des Zaren Samuel; Popović, Das Kloster Hilandar und seine Weidewirtschaft. 


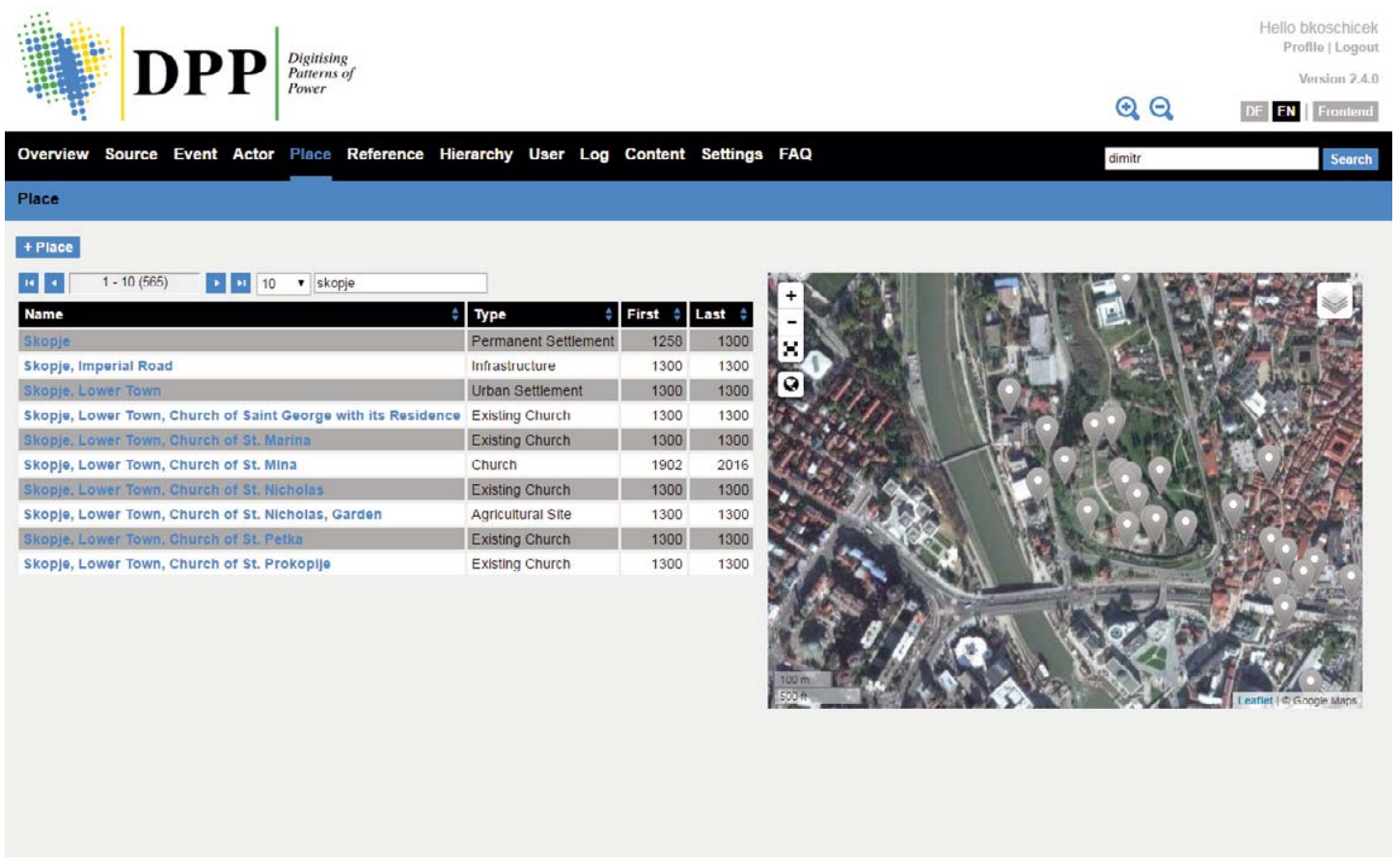

Fig. 5: Entries of Data concerning the Upper Town of Skopje (Entity Place)
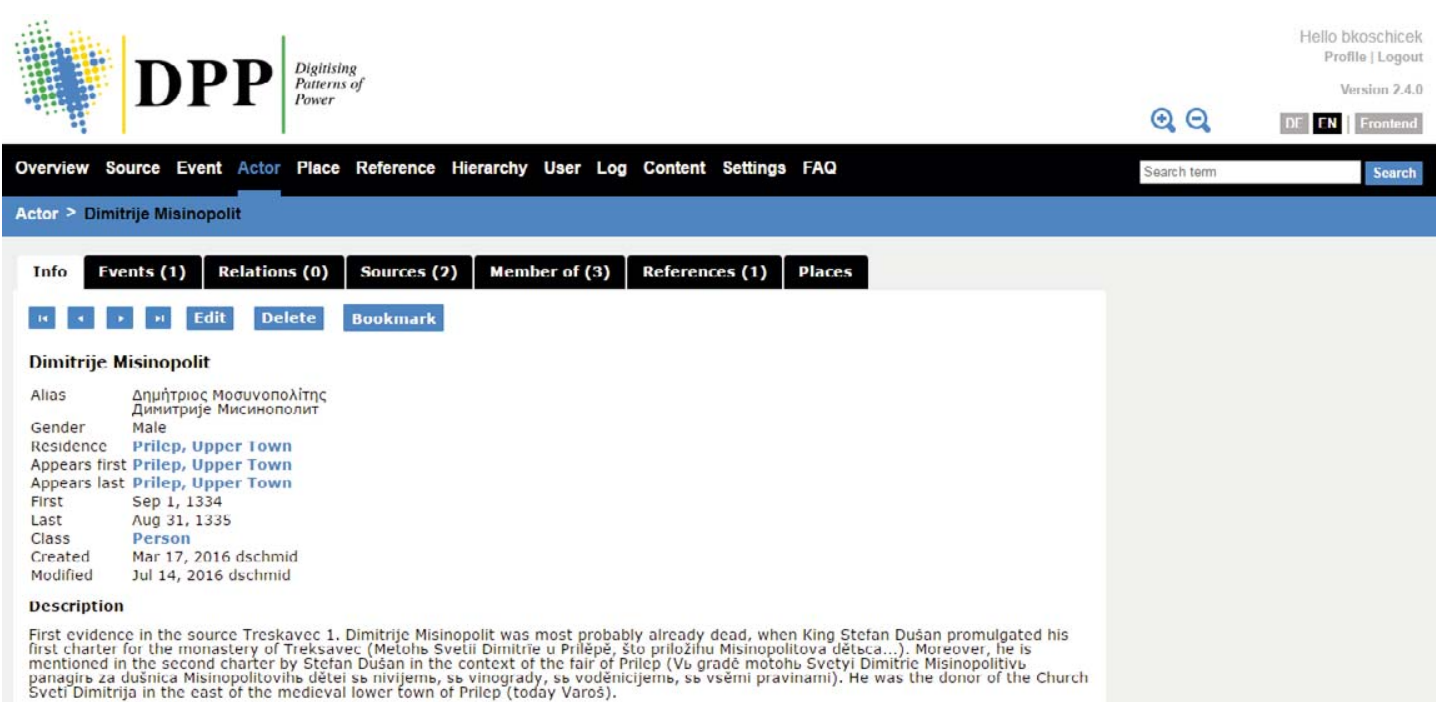

Fig. 6: Biographical Sketch of a Byzantine Nobleman called Dimitrije Misinopolit in the Target Area of Prilep (Entity Actor) 


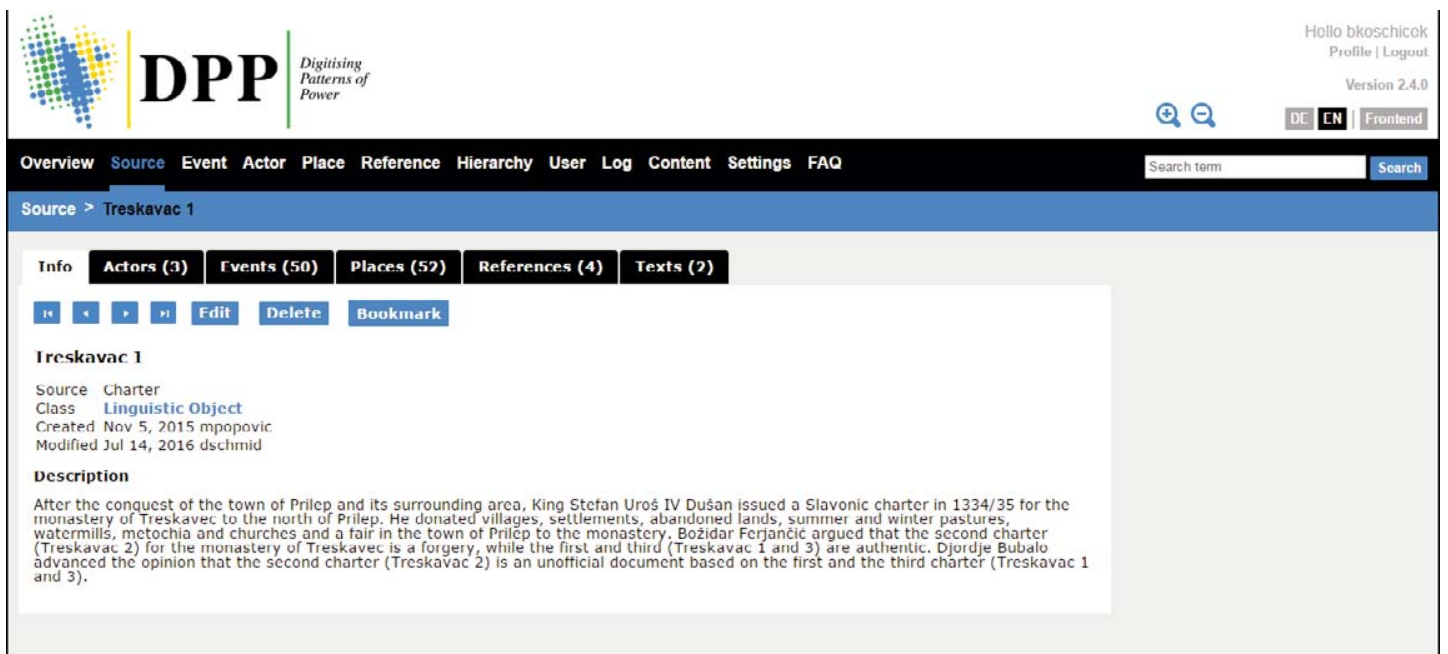

Fig. 7: Entry on the First Serbian Charter for the Monastery of Treskavec, 1334/35 (Entity Source)

In the second year of the project DPP (2016) various new map features were implemented for the DPP OpenAtlas web interface. In written sources very often only vague information is given regarding the spatial position of the named entities. For example, a village, which is mentioned in a charter, might be identified either with a still existing village, the exact extent or shape of which we know; or it might be identified with an abandoned village, which can be attributed to a certain area, and in which it was originally located. In order to be able to deal with this fuzziness of spatial information, we have developed a framework based on Leaflet and PostGIS. This allows the user to draw polygons with the aim of marking the spatial extent of a historical entity or simply to create a centre point of its position (cf. Fig. 8). The respective feature is implemented in the map interface of the web application. Therefore, it is possible to record in our DPP OpenAtlas Database any type of precise or vague localisation without loss of information.

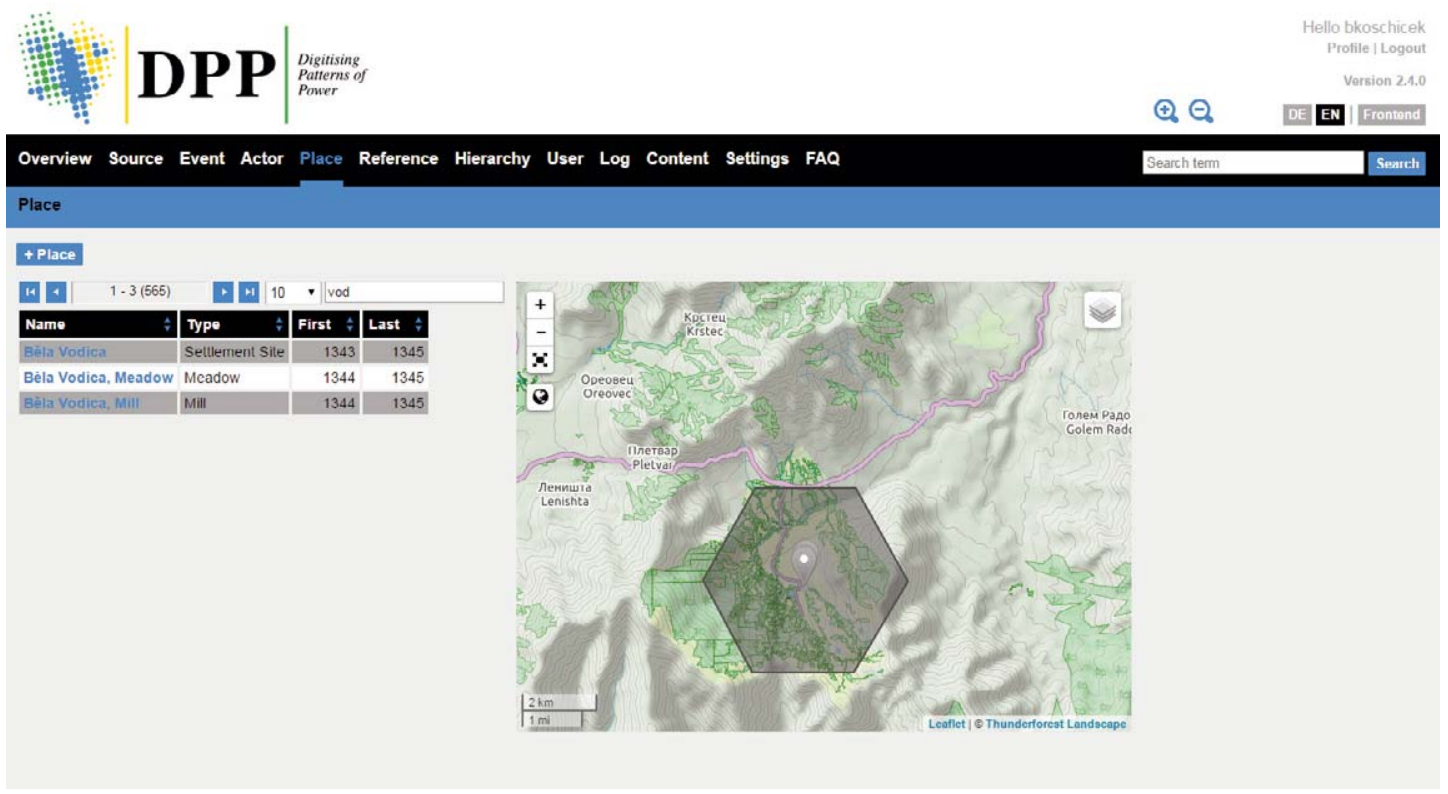

Fig. 8: Fuzzy Localisation of a Meadow and a Mill in the Vicinity of the Settlement Site (selište) of Bèla Vodica 
Regarding the authors' case study »The Historical Region of Macedonia (12th-14th Centuries) - The Transformation of a Medieval Landscape«within DPP, the input of researched and interpreted data has advanced very well. Out of Four Target Areas (cf. Fig. 2) the city of Prilep and its surroundings has been completely embedded into the DPP OpenAtlas Database. The input of data concerning the city of Skopje and its environs has been nearly accomplished, while the analysis and interpretation of sources on the monastery of Lesnovo and its landed property has begun. These tasks are implemented by the authors and their Junior Scientist David Schmid, BA. Based on the settlement theories of Walter Christaller ${ }^{51}$ and on calculations of radii regarding the boundaries of villages in Byzantine Macedonia by Vassiliki $\operatorname{Kravari}^{52}$, the territories of villages are outlined as polygons in hexagonal shape in this case study and consequently in the DPP OpenAtlas Database (cf. Fig. 8).

\section{Outlook for 2017}

The DPP members of the Department of Geography and Regional Research (University of Vienna, Group Leader: Prof. Dr. Karel Kriz) are currently working on the first prototype of the map-based online application, which will be the prominent front end of the DPP project. This application, which is a key aspect of the project, will serve two equally important functions. One will be to enable DPP scholars to view the spatial data and explore spatial relations between different database entities and thus gain insight into the medieval landscape. The second function of the application will be to present the DPP research and its results to an interested public audience. In the final application key DPP results will be communicated via "story maps", predefined views of the data, which will be complemented with a detailed description of the topic shown and information about its significance for historiography. The first prototype offers basic functionality, queries as well as dot representations of the data. It is a testbed for various representations of uncertain geometries to determine which one is best suited for the final application. Step by step, more advanced functions and queries will be implemented and tested in the prototype during the year 2017.

\section{"Signs of Power"}

One of the most important aspects of the joint research work in 2016/17 are the so-called "Signs of Power". These are intended to serve as a designation for special places, in which rulers, or persons empowered by them, exercised and/or represented symbolic, but also concrete power. Papers and discussions at the First International Workshop of DPP entitled "Digitising Patterns of Power (DPP): Theory and Practice in Historical Geography and Digital Humanities«, which took place in September 2016 at the Institute for Medieval Research (IMAFO) of the Austrian Academy of Sciences in Vienna ${ }^{53}$, helped to establish a theoretical basis for the common research question of DPP, namely the definition of "Signs of Power «for all case studies and their representation as »Dynamic Types «within the framework of the DPP OpenAtlas Database. Following the Workshop, members of the DPP project team, namely

51 Christaller, Die zentralen Orte in Süddeutschland; Christaller, Grundgerüst der räumlichen Ordnung in Europa; Christaller, How I Discovered the Theory of Central Places. Also cf. Koder, Land Use and Settlement.

52 Kravari, Habitat rural.

53 Cf. dpp.oeaw.ac.at/workshop/index.php?site=programme (retrieved 25 January 2017). 
Katharina Winckler, Veronika Polloczek, David Schmid, Bernhard Koschicek and Mihailo Popović, defined the respective term "Sign of Power", which was given preference over the term "Symbol of Power", since the English word "Symbol«was seen as a concept, which mainly encompasses intangibles, and, therefore, was deemed too narrow for addressing the analysis of the description of space in written sources, the interactions between natural and cultural space and the rise of new political, religious and economic structures of power.

A type tree for the "Sign of Power «was developed by these scholars at the end of 2016 and has already been implemented in the DPP OpenAtlas Database. The "Signs of Power«will only be tagged within the entity »Places«(cf. Fig. 9).

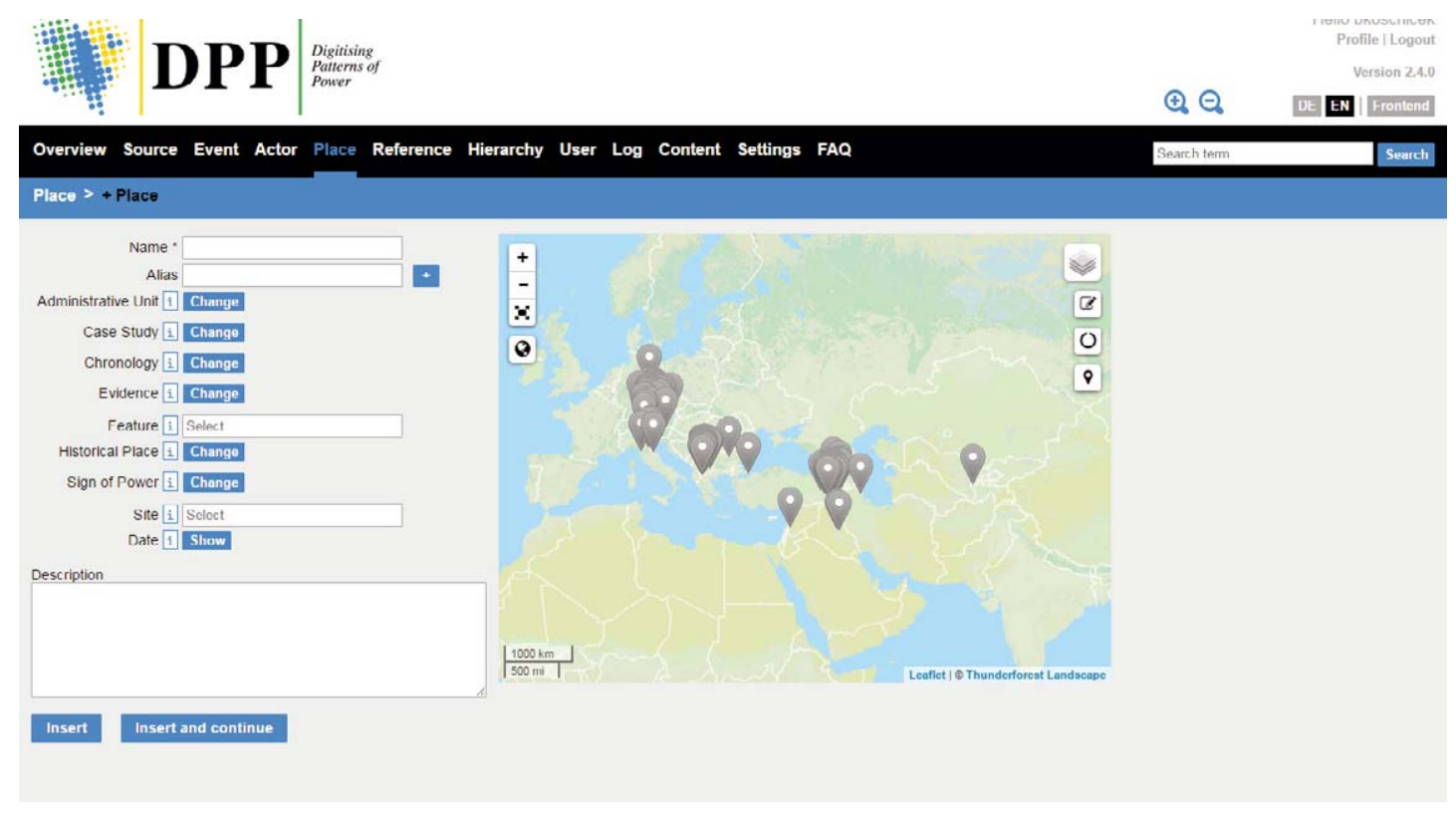

Fig. 9: The Form for the Entity Place and the Category Sign of Power

The "Sign of Power «itself is divided into four large groups, i.e. political, economic, cultic and military, which are again subdivided (cf. Fig. 10):

\section{Political}

- Infrastructure (Residence, Palace, »Pfalz«, etc.)

- Vertical Interaction (the relationship ruler/subordinate; e.g. the ruler X is issuing a charter in the place $\mathrm{X}$ for subordinate $\mathrm{X}$, or subordinate $\mathrm{X}$ is addressing the ruler $\mathrm{X}$ in the place $\mathrm{X}$ in order to acquire privileges)

- Horizontal Interaction (peers meet in the place X, e.g. state councils, synods, councils)

- Item (archaeological finds which represent political power or a specific concentration of finds in place $\mathrm{X}$ )

\section{Economic}

- Infrastructure (bridges, streets, roads, tolls etc.)

- Production Site (mills, vineyards, meadows; includes agricultural as well manual places of production)

- Item (archaeological finds which illustrate the aforesaid aspects; e.g. remnants of roads, coins, etc.) 


\section{Cult (Religious)}

- Infrastructure (buildings: churches, monasteries, metochia, chapels etc.)

- Ritual (dedication, patrocinia, cult of Saints, relics, processions)

- Item (archaeological finds; e.g. traces of churches, crosses, reliquaries, etc.)

\section{Military}

- Troops (individuals who are representing military authority and are garrisoned in a certain place X, e.g. the Byzantine kastrophylax; garrisons, armies in certain places)

- Infrastructure (buildings, castles, watchtowers)

- Item (archaeological finds; e.g. weapons such as swords, armour, smithies, battle fields, etc.)

Fig. 10: The Concept of "Signs of Power" and their Subdivision

Signs of Power

Political

-Infrastructure

-Vertical Interaction

-Horizontal Interaction

- Objects

Economic

-Infrastructure

- Production Site

- Objects

Cult

-Infrastructure

- Ritual

- Objects

Military

- Troops

-Infrastructure

- Objects

The DPP OpenAtlas Database allows the user to tag places with several "Signs of Power«in order to represent places of greater or lesser importance (cf. Fig. 11). 


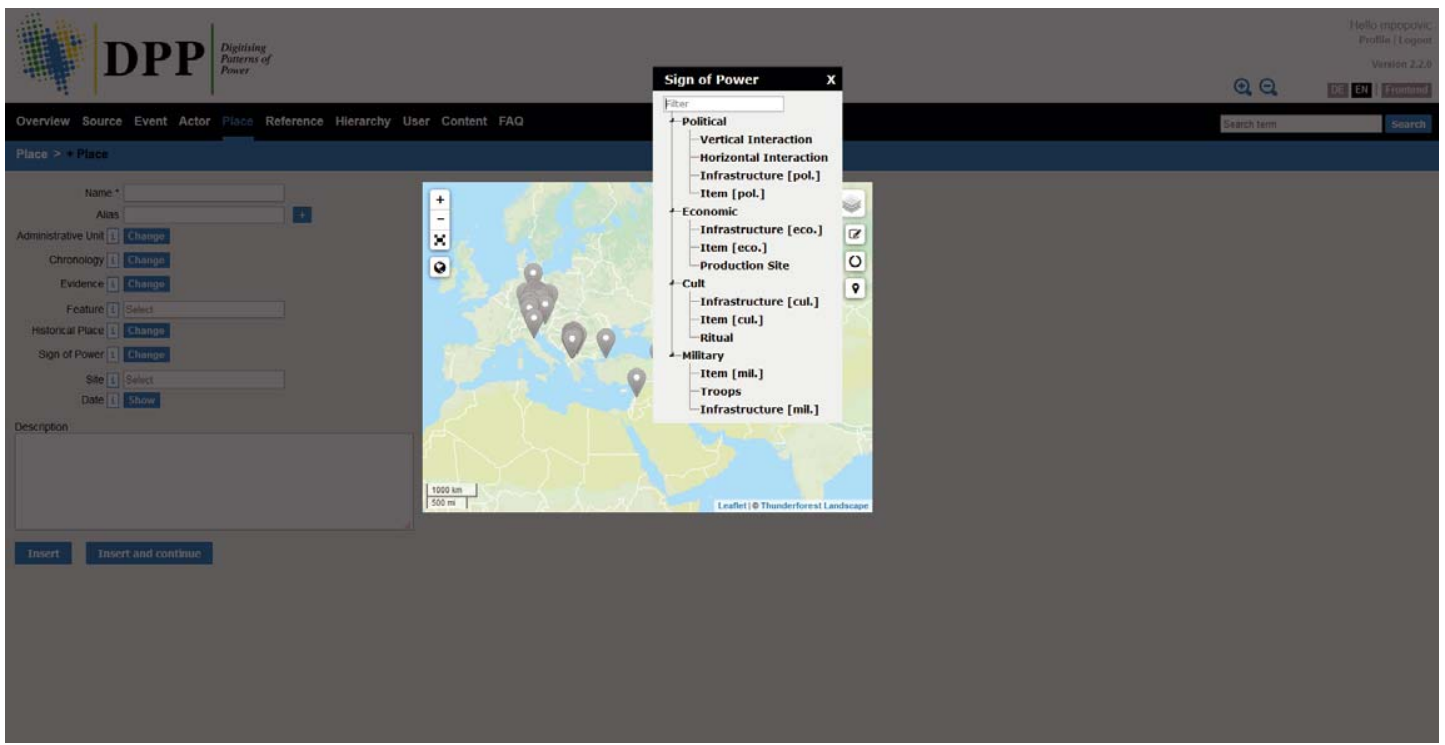

Fig. 11: The Type Tree for the "Sign of Power«in the DPP OpenAtlas Database

In 2017 the respective five case studies will achieve their foremost scholarly aim, which is to accomplish the thorough analysis and interpretation of their data as well as to embed it accurately into the DPP OpenAtlas Database. For the time being, they have to refrain from tagging places with "Signs of Power". Only when a representative body of data in quantity as well as in quality from all five case studies has been stored, a joint, profound discussion within the entire DPP project team will follow, which will lead to a systematic comparison of all areas of research through time and space, the subsequent tagging of data and the visualisation of results - which is altogether the essence of the digital cluster project DPP. 


\section{References}

Abulafia, David, Berend, Nora (eds.), Medieval Frontiers: Concepts and Practices (Aldershot, 2002).

Bakalopulos, Apostolos, Les limites de l'empire byzantin depuis la fin du XIVe siècle jusqu'à sa chute (1453), Byzantinische Zeitschrift 55 (1962) 56-65.

Baramova, Maria, Boykov, Grigor, Parvev, Ivan (eds.), Bordering Early Modern Europe (Wiesbaden, 2015).

Bartusis, Mark C., 'EEA $\mathrm{EIMMA:} \mathrm{Escheat} \mathrm{in} \mathrm{Byzantium,} \mathrm{Dumbarton} \mathrm{Oaks} \mathrm{Papers} 40$ (1986) 55-81.

Bartusis, Mark C., Exaleimma, in: Alexander Kazhdan (ed.), The Oxford Dictionary of Byzantium 2 (New York, 1991) 766.

Bartusis, Mark, The Settlement of Serbs in Macedonia in the Era of Dušan's Conquests, in: Hélène Ahrweiler, Angeliki E. Laiou (eds.), Studies on the Internal Diaspora of the Byzantine Empire (Washington, 1998) 151-159.

Bartusis, Mark, Land and Privilege in Byzantium: the Institution of Pronoia (Cambridge, 2012).

Blagojević, Miloš, Medaković, Dejan, Istorija srpske državnosti. Knjiga I: Od nastanka prvih država do početka srpske nacionalne revolucije (Novi Sad, 2000).

Blagojević, Miloš, Dušanić, Slobodan, Maksimović, Ljubomir, Ljušić, Radoš, Jovanović, Borislav, Ristović, Milan, Dimić, Ljubodrag, Mišić, Siniša, Panić-Štorh, Miroslava, Samardžić, Nikola, Stefanović, Danijela, Istorijski atlas (Beograd, 2002).

Božanić, Snežana, Čuvanje prostora. Međe, granice i razgraničenja u srpskoj državi od 13. do 15. veka (Novi Sad, 2013).

Carter, Francis W., An Analysis of the Medieval Serbian Oecumene: A Theoretical Approach, Geografiska Annaler, Series B, Human Geography 51/1 (1969) 39-56.

Christaller, Walter, Die zentralen Orte in Süddeutschland. Eine ökonomisch-geographische Untersuchung über die Gesetzmäßigkeit der Verbreitung und Entwicklung der Siedlungen mit städtischen Funktionen (Jena, 1933, reprinted Darmstadt, 1968).

Christaller, Walter, Das Grundgerüst der räumlichen Ordnung in Europa. Die Systeme der europäischen zentralen Orte, Frankfurter Geographische Hefte 24/1 (Frankfurt/M., 1950).

Christaller, Walter, How I Discovered the Theory of Central Places: A Report About the Origin of Central Places, in: Paul Ward English, Robert C. Mayfield (eds.), Man, Space and Environment (New York, 1972) 601-610.

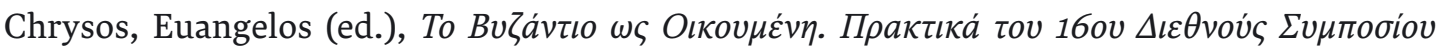
(AӨńva, 2005).

Ćirković, Sima, Blagojević, Miloš, Zbor, in: Sima Ćirković, Rade Mihaljčić (eds.), Leksikon srpskog srednjeg veka (Beograd, 1999) 222-228.

Danilo II, Životi kraljeva $i$ arhiepiskopa srpskih napisao arhiepiskop Danilo $i$ drugi, ed. Djuro Daničić (Zagreb, 1866).

Dinić, Mihailo, Za hronologiju Dušanovih osvajanja vizantiskih gradova, Zbornik radova Vizantološkog instituta 4 (1956) 1-11.

Djoković, Zorica, Stanovništvo istočne Makedonije u prvoj polovini XIV veka. Zbornik radova Vizantološkog instituta 40 (2003) 97-244.

Eger, Alexander Asa, The Islamic-Byzantine Frontier: Interaction and Exchange among Muslim and Christian Communities (London, 2015).

Hafner, Stanislaus, Serbisches Mittelalter. Altserbische Herrscherbiographien. Band 2: Danilo II. und sein Schüler: Die Königsbiographien (Graz, 1976). 
Haldon, John F., Kennedy, Hugh, The Arab-Byzantine Frontier in the Eighth and Ninth Centuries: Military Organisation and Society in the Borderlands, Zbornik radova Vizantološkog instituta 19 (1980) 79-116.

Haldon, John, Res publica Byzantina? State Formation and Issues of Identity in Medieval East Rome, Byzantine and Modern Greek Studies 40/1 (2016) 4-16.

Jaspert, Nikolas, Grenzen und Grenzräume im Mittelalter: Forschungen, Konzepte und Begriffe, in: Klaus Herbers, Nikolas Jaspert (eds.), Grenzräume und Grenzüberschreitungen im Vergleich. Der Osten und der Westen des mittelalterlichen Lateineuropa, Europa im Mittelalter 7 (Berlin, 2007) 43-70.

Kaegi, Walter Emil Jr., The Frontier: Barrier or Bridge?, in: Gary Vikan (ed.), The 17th International Byzantine Congress. Major Papers, Dumbarton Oaks/Georgetown University, Washington D.C., August 3-8, 1986 (New York, 1986) 279-303.

Kaldellis, Anthony, The Byzantine Republic: People and Power in New Rome (Cambridge, MA, 2015).

Kalić, Jovanka, Les migrations serbes dans les Balkans, in: The Balkans and the Eastern Mediterranean 12th-17th Centuries. Proceedings of the International Symposium in Memory of D. A. Zakythinos, Athens, January 14th-15th 1994, The National Hellenic Research Foundation, Institute for Byzantine Research, Byzantium Today 2 (Athens, 1998) 121-125.

Koder, Johannes, $\mathrm{Zu}$ den Folgen der Gründung einer zweiten Reichshauptstadt an der "Peripherie«des Römischen Reiches am Übergang von der Antike zum Mittelalter, SüdostForschungen 48 (1989) 1-18.

Koder, Johannes, Perspektiven der Tabula Imperii Byzantini. Zu Planung, Inhalt und Methode, Geographia antiqua 5 (1996) 75-86.

Koder, Johannes, Macedonians and Macedonia in Byzantine Spatial Thinking, in: John Burke, Roger Scott (eds.), Byzantine Macedonia: Identity, Image and History: Papers from the Melbourne Conference July 1995, Byzantina Australiensia 13 (Melbourne, 2000) 12-28.

Koder, Johannes, Die räumlichen Vorstellungen der Byzantiner von der Ökumene (4. bis 12. Jahrhundert), Anzeiger der philosophisch-historischen Klasse der Österreichischen Akademie der Wissenschaften 137/2 (2002) 15-34.

Koder, Johannes, Land Use and Settlement: Theoretical Approaches, in: John F. Haldon (ed.), General Issues in the Study of Medieval Logistics: Sources, Problems and Methodologies, History of Warfare 36 (Leiden, 2006) 159-183.

Kravari, Vassiliki, L'habitat rural en Macédoine occidentale (XIIIe-XIVe siècles), in: Klaus Belke, Friedrich Hild, Johannes Koder, Peter Soustal (eds.), Byzanz als Raum. Zu Methoden und Inhalten der historischen Geographie des östlichen Mittelmeerraumes, Veröffentlichungen der Kommission für die Tabula Imperii Byzantini 7 (Wien, 2000) 83-94.

Lefort, Jacques, Population et peuplement en Macédoine orientale, IXe-XVe siècle, in: Hommes et richesses dans l'Empire byzantin, Tome II, VIIIe-XVe siècle (Paris, 1991) 63-89.

Levi, Giovanni, On Microhistory, in: Peter Burke (ed.), New Perspectives on Historical Writing (Cambridge, 1991) 97-119.

Magnússon, Sigurđur Gylfi, Szijártó, István, What is Microhistory? Theory and Practice (London, 2013).

Maksimović, Ljubomir, Makedonija u politici srednjovekovne Srbije, Glas 404 Srpske Akademije Nauka i Umetnosti, Odeljenje istorijskih nauka knj. 13 (2006) 29-50.

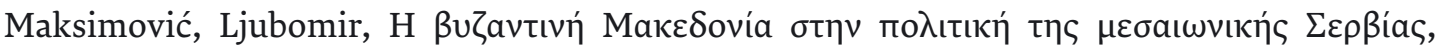

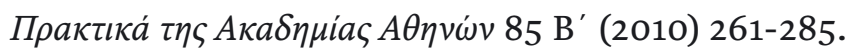


Mihaljčić, Rade, Selišta. Prilog istoriji naselja u srednjovekovnoj srpskoj državi, Zbornik Filozofskog Fakulteta 9/1 (Beograd, 1967) 173-224.

Moustakas, Konstantinos, The Demographic Crisis of the Late Middle Ages in the Greek Lands: the Case of South-Eastern Macedonia (14th-15th C.), Mvin $\mu \nu 25$ (2003) 9-33.

Naumov, Evgenij P., K istorii serbo-vizantijskoj granicy vo vtoroj polovine XIV v, Vizantijskij Vremennik 25 (1964) 231-234.

Obolensky, Dimitri, The Byzantine Commonwealth. Eastern Europe, 500-1453 (London, 1974).

Ostrogorskij, Georges, Étienne Dušan et la noblesse serbe dans la lutte contre Byzance, $B y$ zantion 22 (1952) 151-159.

Ostrogorskij, Georges, Pour l'histoire de la féodalité byzantine. Traduction française de Henri Grégoire, publiée avec la collaboration de Paul Lemerle, Corpus Bruxellense Historiae Byzantinae, Subsidia I (Bruxelles, 1954).

Petrovski, Boban, Prilog kon prašanjeto za pagjanjeto na Štip pod srpska vlast vo prvata decenija na XIV vek, Godišen Zbornik Filozofski Fakultet na Univerzitetot »Sv. Kiril i Metodij» - Skopje 26/52 (1999) 141-153.

Pirivatrić, Srdjan, Ulazak Stefana Dušana u Carstvo, Zbornik radova Vizantološkog instituta 44/2 (2007) 381-409.

Podskalsky, Gerhard, Theologische Literatur des Mittelalters in Bulgarien und Serbien 8651459 (München, 2000).

Podskalsky, Gerhard, Briefe in der mittelalterlichen Literatur Bulgariens und Serbiens, in: Lars M. Hoffmann, Anuscha Monchizadeh (eds.), Zwischen Polis, Provinz und Peripherie. Beiträge zur byzantinischen Geschichte und Kultur, Mainzer Veröffentlichungen zur Byzantinistik 7 (Wiesbaden, 2005) 571-577.

Popović, Marko, Les forteresses dans les régions des conflits byzantino-serbes au XIVe siècle, in: Byzantium and Serbia in the 14th Century, International Symposium 3 (Athens, 1996) 67-87.

Popović, Mihailo St., Siedlungsstrukturen im Wandel. Das Tal der Strumica bzw. Strumešnica in spätbyzantinischer und osmanischer Zeit (1259-1600), Südost-Forschungen 68 (2009) 1-62.

Popović, Mihailo, Mapping Byzantium - The Project »Macedonia, Northern Part«in the Series Tabula Imperii Byzantini (TIB) of the Austrian Academy of Sciences, in: Mapping Different Geographies, Lecture Notes in Geoinformation and Cartography (Berlin, 2010) 219-234.

Popović, Mihailo St., Altstraßenforschung am Beispiel des Tales der Strumica bzw. Strumešnica in spätbyzantinischer Zeit (1259-1375/76), in: Miša Rakocija (ed.), Niš i Vizantija. Osmi naučni skup, Niš, 3-5. jun 2009. Zbornik radova VIII (Niš, 2010) 417-432.

Popović, Mihailo St., Das Flußtal der Kriva Lakavica in spätbyzantinischer und osmanischer Zeit (1259-1600): Das Verhältnis des Ortes Konče zum Siedlungsnetz der Städte Štip und Strumica, Revue des Études Byzantines 69 (2011) 159-184.

Popović, Mihailo St., Networks of Border Zones: A Case Study on the Historical Region of Macedonia in the 14th Century AD, in: Karel Kriz, William Cartwright, Michaela Kinberger (eds.), Understanding Different Geographies, Lecture Notes in Geoinformation and Cartography (Berlin, 2013) 227-241.

Popović, Mihailo St., Historische Geographie und Digital Humanities. Eine Fallstudie zum spätbyzantinischen und osmanischen Makedonien, Peleus. Studien zur Archäologie und Geschichte Griechenlands und Zyperns 61 (Mainz, 2014). 
Popović, Mihailo St., L'Espace impérial, l'Espace contesté: le sud-est de la Macédoine entre Byzance et l'Empire serbe, in: Zbornik radova u čast akademiku Desanki Kovačević Kojić, Akademija nauka i umjetnosti Republike Srpske, Zbornik radova, Knjiga 10, Odjeljenje društvenih nauka, Knjiga 38 (Banja Luka, 2015) 409-425.

Popović, Mihailo St., Das Herrschaftsgebiet des Zaren Samuel im Mittelalter und dessen Erforschung zwischen 1890 und 1918, in: Kongreßband "Evropejskijat jugoiztok prez vtorata polovina na X - načaloto na XI vek. Istorija i kultura. Meždunarodna konferencija, Sofija, 6-8 oktomvri 2014 g.«(Sofija, 2015) 277-298.

Popović, Mihailo St., Die Topographie der mittelalterlichen Stadt Skopje zwischen byzantinischem und serbischem Reich (13.-14. Jh.), Initial, A Review of Medieval Studies 3 (Belgrade, 2015) 35-55.

Popović, Mihailo St., Das Kloster Hilandar und seine Weidewirtschaft in der historischen Landschaft Mazedonien im 14. Jahrhundert, in: ПEPIBO $O \Sigma$ - Mélanges offerts à Mirjana Živojinović, Tome I. (Beograd, 2015) 215-225.

Popović, Mihailo St., The "Medieval Serbian Oecumene«- Fiction or Reality?, in: Vesna Bikić (ed.), Byzantine Heritage and Serbian Art I. Process of Byzantinisation and Serbian Archaeology (Belgrade, 2016) 37-43.

Popović, Mihailo St., "Srednjovekovna srpska ekumena«- fikcija ili stvarnost?, in: Vesna Bikić (ed.), Vizantijsko nasledje i srpska umetnost I. Procesi Vizantinizacije i srpska arheologija (Beograd, 2016) 37-43.

Popović, Mihailo St., Le changement des élites en Macédoine face à l'expansion serbe - Le cas de Skopje et ses environs au 14e siècle, in: Proceedings "Colloque International Byzance et ses voisins, XIIIe-XVe siècle : art, identité, pouvoir «- forthcoming.

Putzger, Friedrich Wilhelm, Historischer Weltatlas zur allgemeinen und österreichischen Geschichte (Wien, 1977).

Radojčić, Nikola, Srpski državni sabori u srednjem veku (Beograd, 1940).

Rapp, Stephen H. Jr., Chronology, Crossroads, and Commonwealths: World-Regional Schemes and the Lessons of Caucasia, in: Interactions: Transregional Perspectives on World History (Honolulu, 2005) 167-201.

Schmalzbauer, Gudrun, Überlegungen zur Idee der Oikumene in Byzanz, in: Wolfram Hörandner, Johannes Koder, Maria A. Stassinopoulou (eds.), Wiener Byzantinistik und Neogräzistik. Beiträge zum Symposion Vierzig Jahre Institut für Byzantinistik und Neogräzistik der Universität Wien im Gedenken an Herbert Hunger (Wien, 4.-7. Dezember 2002), Byzantina et Neograeca Vindobonensia 24 (Wien, 2004) 408-419.

Schwara, Desanka, Rediscovering the Levant: a Heterogeneous Structure as a Homogeneous Historical Region, European Review of History 10/2 (2003) 233-251.

Škrivanić, Gavro A., O južnim i jugoistočnim granicama srpske države za vreme cara Dušana i posle njegove smrti, Istorijski časopis 11 (1960) 1-15.

Stephenson, Paul, The Byzantine Frontier in Macedonia, Dialogos 7 (2000) 23-40.

Stephenson, Paul, Byzantium's Balkan Frontier: a Political Overview, 900-1204, Acta Byzantino Fennica 10 (2000) 65-79.

Stephenson, Paul, Byzantium's Balkan Frontier: a Political Study of the Northern Balkans, 90o1204 (Cambridge, 2000).

Slaveva, Lidija, Mošin, Vladimir, Srpski gramoti od Dušanovo vreme (Prilep, 1988).

Smith, Monica L., Networks, Territories, and the Cartography of Ancient States, Annals of the Association of American Geographers 95/4 (2005) 832-849. 
Smith, Monica L., Territories, Corridors, and Networks: A Biological Model for the Premodern State, Complexity 12 (2007), 28-35.

Šuica, Marko, Nemirno doba srpskog srednjeg veka. Vlastela srpskih oblasnih gospodara (Beograd, 2000).

Szijártó, István, Four Arguments for Microhistory, Rethinking History 6/2 (2002) 209-215.

Tomoski, Tomo, Ispravki i dopolnenija na nekoi karti od srednovekovnata istorija na Makedonija. Godišen Zbornik Filozofski Fakultet na Univerzitetot - Skopje 7 (1954) 111-122.

Trapp, Erich (ed.), Prosopographisches Lexikon der Palaiologenzeit, Fasz. 1-12 (Wien, 19761996).

Živojinović, Mirjana, La frontière serbobyzantine dans les premières décennies du XIVe siècle, in: Byzantium and Serbia in the 14th Century, International Symposium 3 (Athens, 1996) 57-66. 